\title{
The China-Pakistan Economic Corridor (CPEC): Considering Contemporary Pakistan through Old-Fashioned Economics and Historical Case Studies
}

\section{Matthew McCartney*}

\begin{abstract}
As part of the massive One Belt One Road (OBOR) project or 'New Silk Road' the governments of China and Pakistan have announced that a significant 'corridor' will be constructed in Pakistan. This paper looks in detail at the $\$ 46$ billion China-Pakistan Economic Corridor (CPEC) package of transport, energy and manufacturing projects and asks how we can analyse the impact of a transformative expansion of infrastructure. This paper draws lessons from various old-fashioned economics including Rostow, Hirschman and others and the historical case studies of transformative infrastructure expansion in the nineteenth century United States, Mexico, Germany and India to explore the conditions under which CPEC could promote sustainable long-run economic growth in Pakistan.
\end{abstract}

Keywords: Pakistan, China, China-Pakistan Economic Corridor (CPEC), growth.

JEL classification: O10.

\section{Introduction}

Much has been written about the China-Pakistan Economic Corridor (CPEC) ${ }^{1}$. Many of these writings are brimming with optimism such as the definition of CPEC as given by the Government of Pakistan, "a growth axis and development belt featuring complementary advantage, collaboration, mutual benefits and common prosperity." (2017:4). The promised investment in CPEC (US\$46 billion) is enormous relative to the cumulative Foreign Direct Investment (FDI) Pakistan received between 1970 and 2001 (around US\$7 billion) (Atique et al., 2004). CPEC can represent more than just a boost to economic growth. The explicit longterm commitment of investment can assist Pakistan in making a decisive

\footnotetext{
* Associate Professor, University of Oxford, Matthew.McCartney@ area.ox.ac.uk

${ }^{1}$ Thanks to three anonymous reviewers who provided very useful feedback and also to the scholars and students of the Institute of International Area Studies (IIAS) at Tsinghua University in Beijing where the final revisions of this paper were completed.
} 
break with the decades-long dependence on the fickle whims of U.S. policy (McCartney, 2011). There is need for more careful reflection. CPEC is not due for completion until 2030 and Pakistan has a dire record of implementing and benefiting from large-scale donor funded projects - the unsuccessful Social Action Program (SAP) in the 1990s being just one such example (Birdsall \& Kinder, 2010).

It is not easy to make a rigorous assessment about whether CPEC is likely to be an economic success. Economics, particularly its neo-classical branch, is very well suited to examining the impact of marginal changes to the economic environment. When it comes to how a new road, bridge or railway track will impact various markets and economic outcomes, economics has a well-developed methodology for doing just this - Cost Benefit Analysis (CBA) (see Gunasekara et al (2008) for an example in the South Asian region). The academic problem stems from the promise of CPEC - that it will represent a transformational and wide-ranging change to existing economic relations. These changes cannot be captured by a methodology geared to economic shifts at the margin.

This article offers a contribution to this theoretical and empirical dilemma. Often forgotten amidst the excitement surrounding CPEC is that, while it is unprecedented for contemporary Pakistan, there are many historical examples of transformational infrastructural change - among those discussed in this paper are the massive (much greater than CPEC) expansions of the railway systems in nineteenth century India, Mexico, the U.S. and Germany. This paper tries to draw out lessons from these historical case studies to inform our understanding of contemporary Pakistan. This paper will also make the case that there is a neglected body of economic theory more suitable to engage with such a question than CBA. This theory derives from the writings of the early development economists - like Rostow, Rosenstein-Rodan and Hirschman - whose starting point was not marginal interventions and consequent shifts in equilibrium, but was that of transformational change in the entire structure of an economy. While they were writing about the shift from a ruralagricultural to an urban-industrial economy we can profitably draw from their discussion to consider the possible impact of a transformational change in infrastructure.

This paper is organised as follows: section 2 examines the economics of geography to explain why transport infrastructure is important, section 3 introduces CPEC, section 4 examines the work of the early development economists, section 5 considers problems with existing 
studies and proposes a possible methodology, section 6 considers the possible impact of CPEC on making markets more efficient, and section 7 on whether CPEC will more likely promote industrialization or deindustrialization in contemporary Pakistan. Section 8 concludes and draws together the lessons from this paper into a research agenda.

\section{Why Transport Infrastructure is Important}

The deep determinants of economic growth are those underlying factors that influence the ability of firms, households and the government to acquire land, labor, capital and technology. These factors are utilized to increase output and to do so productively. Other deep determinants of economic growth include institutions, history, culture and openness (McCartney, 2015).

The geography hypothesis argues that the geographical endowments of a country or state are the most important influence on long term growth and productivity. There are five major mechanisms through which geography can influence economic growth. These are proximity to or ownership of natural resources (Collier, 2007), state formation (Diamond, 1999), human health (Sachs et al., 2004), agricultural productivity (Bloom et al., 1998) and - of particular importance to this paper - transport costs. The economic analysis of infrastructure (and of CPEC in particular as discussed in this paper) is ultimately justified by the argument that geography has been shown to be a deep determinant of economic growth.

There is compelling evidence that geography has had an enduring and important economic impact. A global map showing GDP per capita in 1995 shows that tropical countries (those nearer the equator) tend to be poor, and also that landlocked countries are poorer than countries with access to the coast. Of the top thirty countries ranked by 1995 PPP-adjusted GDP per capita, only two are tropical (Hong Kong and Singapore), four are sub-tropical, and 23 are located in a temperate zone. This evidence uses single countries as data points such that India and the U.S. were considered coastal, despite having large portions of their land area located far from the coast. Nordhaus (2006) overcame the crudity of this early work by using gridded data. He divided the world into almost 20,000 data points, rather than the 150 country observations previously used. This approach allowed Nordhaus to use more finely tuned geographic data (including climate, location, distance from markets or seacoasts, and soils) which are organized by geography rather than political borders. Nordhaus confirms 
the importance of geography and the significant positive link from temperate climates and costal location to economic outcomes.

Gallup and Sachs (1999) use data from 150 countries (with populations above 1 million) for the period 1960 to 1990 and control for the influence of economic and political institutions. They find four geographic variables (the prevalence of malaria, transport costs, the proportion of the country's population near the coastline, and endowment of hydrocarbons per capita) explain 69 percent of cross-country variation in per capita income. Bloom et al. (1998) examine data for 77 countries from 1965 to 1990 and find that the percentage of a country's land area in the tropics and the density of population within $100 \mathrm{~km}$ of the coast accounts for 73 percent of the income gap between Sub-Saharan Africa and East and Southeast Asia. The most important geographical variables Warner (2002) finds are tropical location, remoteness from the coast or a river, and mountainous terrain. In India the richest and fastest growing states in recent decades have tended to be coastal rather than landlocked (Kurian, 2000).

Transport costs are a product of geography and are those extra costs imposed by being a landlocked country, having population far from the coast or being far from domestic or large international markets. Transport costs are positively related to the distance of the country from core areas of the world economy and to the accessibility of the country to sea-based trade. Half of world trade takes place among countries located within a 3,000 km radius of each other (Gallup \& Sachs, 1999). This is a particular problem for Sub-Saharan Africa. In 1990 the average distance of Sub-Saharan African countries from their trading partners was over $7,800 \mathrm{~km}$ and that Africa is also fragmented into nearly 50 countries each with an average four neighbours, many of which must be crossed to reach the coast. Coulibaly and Fontagne (2005) find that trade with the rest of the world is on average 60 percent lower for landlocked Sub-Saharan African countries. A specific example is the transport inefficiencies that impose significant cost on Ugandan exporters. These are most pronounced for railway connections through Kenya and the gross inefficiency at the Mombasa port. The route from Kampala to Mombasa should be one week although it is often as long as two months. This makes it difficult for exporters to book space on ships, departure times are often missed at high cost, and goods remain in port for long periods. Exporters rely on roads despite the high cost and increased risk of theft. The cost imposed on domestic producers by geography and inefficient transport was equivalent to an effective rate of protection of 48 percent on average in 1994 (Milner et al., 2000). 
Any transport solution to the problems of geography will involve overcoming significant market failures. For a landlocked region in Pakistan (or another country), there are crucial external benefits to investment in transport infrastructure by regions or countries lying between them and the coast. Improving the railway line in the Punjab region, for example, would have little effect unless there was similar improvement to the line as it passed through Sindh or Balochistan on the way to ports in Gwadar or Karachi. Why should Sindh or Balochistan take into consideration those external benefits to investment for the Punjab region? This market failure relates to the external or spillover effects of transport infrastructure investment. There are also market failures related to the role of public investment in infrastructure creating profitable investment opportunities for the private sector. Crowding-in occurs when private sector investment is conditional or contingent on public investment. This is for various reasons, including the long-gestation of investments such as power-supply, the limited size of domestic capital markets, the risk of large investments without precedent in a developing country, and the fact that much of the benefit from such projects is external to the original investment. Investment in energy supply, for example, may not generate much return for the government but such investment may create profitable investment opportunities in private sector manufacturing (Hirschman, 1958). There has been some work on crowdingin of private investment in the Pakistani context. The general finding is that public investment has a positive impact on private investment (Khan, 1988; Hyder, 2001; Naqvi, 2002; Ahmed \& Qayyam, 2007) though some argue the opposite (Ghani \& Ud Din, 2006).

\section{The China-Pakistan Economic Corridor}

China and Pakistan have a long-established history of economic links. Bilateral trade and commercial ties were established in January 1963 with the signing of the first long-term trade agreement. In November 2006, China and Pakistan signed a free-trade agreement which was extended to services in 2009. China-Pakistan trade increased from a little over US\$4 billion in 2006-07 to US\$9.2 billion in 2012-13 (Sial, 2017). These trade policy agreements have recently been supplemented by a renewed emphasis on improving infrastructure. The construction of a nearly 3,000 km $(1,800$ mile) infrastructure link from Kashgar in Western China to the deep sea port of Gwadar in southern Pakistan was discussed during the visit to Pakistan of Chinese Premier Li Keqiang in 2013. The link became known as CPEC and includes oil and gas pipelines, railways, highways, special economic zones and fiber optic networks (Sial, 2017). CPEC is part of a huge infrastructure project that will involve more than sixty countries 
known as the One Belt One Road (OBOR). OBOR has become an integral part of Chinese foreign policy under President Xi Jiping (Boyce, 2017).

There are deeper historical precedents for the construction of transport linkages in Pakistan motivated in part by the geopoliticaleconomic interests of external powers. The British constructed a railway to the Khunjerab Pass in Gilgit-Baltistan where it crosses into China. This renewed emphasis on railways linked up the border of Afghanistan in 1926. The Chinese constructed the 1300 km Karakoram Highway in the 1960s to connect Hasan Abdal in the Punjab region to the Khunjerab Pass in Gilgit-Baltistan where it crosses into China. The renewed emphasis on CPEC dates back to policy decisions in 2010 China to develop the western parts of China to close the gap in economic development with eastern and coastal China. The CPEC project has emphasized extending infrastructure and energy projects into Pakistan to link up western China with the rest of the world (Summers, 2016).

There is clear and widespread support for CPEC in Pakistan that was sustained through the change of government in Pakistan in the 2014 national election. The military have also confirmed their enthusiastic backing. To date the main exception has come from some minor regional nationalist parties in Balochistan (Sial, 2017). There is enormous and widespread optimism about CPEC; it "will be a harbinger of economic prosperity and well-being for Pakistan, China and the neighboring states" (Hali et al., 2015). CPEC is clearly in tune with the well-established government policy of giving priority to infrastructure, especially energy. There is good evidence that the provision of infrastructure in Pakistan is poor relative to large comparator developing countries and has become a significant constraint on economic growth (Loayza \& Wada, 2012). CPEC is projected to cost US\$46 billion, of which 71 percent is to be invested in energy, 4 percent in the Gwadar port, 8 percent in rail and 13 percent in road links (Boyce, 2017). The link to the port is likely to be highly significant, as in 2014-15 95 percent of Pakistan's foreign trade (US\$46 billion of imports and US $\$ 23.7$ billion of exports) transited through the three ports of Karachi, Qasim and Gwadar (Boyce, 2017).

\section{How to Study the Economic Impact of Transformational Infrastructure}

There is widespread agreement that CPEC will represent a transformational impact on Pakistan. "The CPEC is a growth axis and development belt featuring complementary advantage, collaboration, mutual benefits and common prosperity" (Government of Pakistan, 2017). 
While conventional neoclassical economics offers a useful framework to analyze how marginal changes will push an economy towards a new equilibrium, it is a less suitable theoretical framework for examining transformational changes. There are various old-fashioned theoretical perspectives that can be called upon to analyze how a transformational change in the provision of infrastructure will likely impact economic growth. These theories date back to the early years of development economics when scholars were seeking to better understand the nature of the transformational shift represented by an agrarian economy undergoing industrialization.

There is a long-standing body of theoretical work, from those early years of development economics that emphasized the importance of a big push (something like CPEC) to launch a poor developing county into selfsustained economic growth. Rosenstein-Rodan (1943) argued for the simultaneous planning of several complementary industries on the basis that employment and income growth in each would create a corresponding demand for the output of the other industries and lead to broad-based sustained economic growth. Rostow $(1956,1960)$ places what he calls the take-off into a longer-term perspective and adds a discussion of complementary social changes to the focus on the economics. Rostow (1956) writes of a "take-off into self-sustained growth" when over two or three decades the economy and society transform themselves in such way that subsequent economic growth is more or less automatic. There is more to this than just policy change as these "[i]nitial changes in method require that some group in society have the will and the authority to install new production techniques" (Rostow, 1956,). Relevant for our study of CPEC is his argument that the "beginning of take-off can usually be traced to a particular sharp stimulus. The stimulus may take the form of a political revolution which affects the balance of social power and effective values, the character of economic institutions, the distribution of income, the pattern of investment outlays and the proportion of potential innovations actually applied" (Rostow 1960,). Could the unusually wide agreement in Pakistan encompassing both political and military elites be likened to such a Rostowian political revolution?

Rostow (1960) provides us with a useful framework in which we can analyze the success (or otherwise) of CPEC. A take-off, he argues, requires three related conditions. "Firstly, a rise in the rate of productive investment from 5 percent or less to 10 percent of national income. Secondly, the development of one or more substantial manufacturing sectors, with a high rate of growth. Thirdly, the existence or quick emergence of a political, social and institutional framework which exploits 
the impulse to expansion in the modern sector and the potential external economy effects of the take-off and gives growth an on-going character." The relevance of this to contemporary Pakistan at first glance may appear a little tenuous. Pakistan boosted its investment from 5 to 10 percent of GDP and beyond in the early 1950s. Rapid manufacturing growth that created a modern industrial sector (textiles) can be dated back to the 1960s. The emergence of a pro-growth institutional framework has often been doubted, but it is nevertheless true that Pakistan has experienced an average of 5 percent GDP growth p.a. and, according to Word Bank data, not had a recession since at least 1960 . This certainly can be considered growth with an on-going character. So perhaps here, we should modify Rostow: we should not be analyzing CPEC as potentially initiating a takeoff, but as, at most, re-starting a stalled take-off.

Of more clearly obvious relevance from Rostow to Pakistan are his discussions of the wide variety of those leading sectors that can contribute to the take-off. Historically, Rostow noted this included, among others, the use of the steam-saw in the Swedish pulp industry (1890-1920), cotton textiles in Britain (1819-48), and the export of silk thread in Japan (1900-1920). Of more direct relevance to Pakistan is that Rostow argued that the 'growth and modernization of the armed forces' played a role as the leading sector in the take-off of Germany, Japan and Russia. Also of very clear relevance for CPEC is that Rostow (1960) argued that historically the introduction of the railroad has been "the most powerful single initiator of take-offs." He argues that railways were decisive in the U.S., France, Germany, Canada, Russia and played a very important part in Sweden and Japan. The railway had three major contributions to the take-off: firstly, lowering internal transport costs, bringing new regions and products to the market and widening the market for producers; secondly, generating large-scale exports; and thirdly, the expansion of the railway directly boosting the modern coal, iron and engineering industries. We must remember though, while the growth of the railway (think large scale infrastructure provision in CPEC) has generated self-sustaining economic growth, this has not always been the case. Rostow also argues that the expansion of railways was less successful in nineteenth century India and China, in Canada pre-1895, and in Argentina. This evidence indicates that there is nothing automatic about the benefits of CPEC and so we must be cautious regarding both the developmental benefits of big infrastructure projects and the widespread optimism surrounding CPEC in Pakistan and China. History offers many examples of otherwise productive investments failing to generate wider economic growth. The exemplar is the plantation or mechanized extractive 
sector. In such sectors the investment financing is often from overseas developed countries, the output is entirely exported, much of the managerial expertise and capital equipment is imported, the consumption goods of senior managers are imported, and much of the profit from production is remitted back to shareholders in the home country. There are so few linkages with the domestic, host economy that such sectors can be likened to "domestic investment on the part of industrialized countries" (Weisskoff \& Wolff, 1977).

Such thinking is not just a relic of colonial economic history (for example, it was much applied to the jute, tea and opium plantations of nineteenth century India). Even the software-IT sector in 1990s India bore many of these characteristics. Software was clearly a success in some ways. The IT sector in India experienced annual output growth of 30 percent p.a. for much of the 1990s. Total revenues of the IT services and software sector reached US\$16.5 billion and exports US\$12.2 billion in 2004-05, with the latter showing growth of 32.3 percent over the year. Such high rates of growth of output and exports had never been recorded by India's manufacturing sector (Balakrishnan, 2006). But during this decade the sector bore some uncanny resemblence to a nineteenth century tea plantation. Ninety percent of the output of the software sector was exported. This meant that production and resultant learning by software firms was geared to the needs of the high-technology economy of Silicon Valley in the U.S., so had little link with the needs of the developing country of India. Skills acquired by software engineers were more likely to lead to international migration and brain drain than those skills being transferred to other sectors in the domestic economy. The finished software and hardware used by the industry was largely imported meaning that net exports (of this very import-intensive sector) were actually much lower than the impressive headline figures (Chakraborty \& Jayachandran, 2001; Balakrishnan, 2006; Kapur, 2007). However, there is increasing agreement that these enclave-like features declined in the 2000s, when software took on more of the characteristics of a leading sector (Kite, 2013).

The lesson from this particular concern is that we need to go beyond measures of the success of CPEC itself - freight volume at Gwadar or transit volumes on the new highways, for example. The expansion of one sector can promote wider economic growth through spillovers and these need to be carefully considered in any discussion of the CPEC. The theoretical literature identifies four channels through which spillovers may boost productivity in the host economy: imitation, skills acquisition, competition and exports. Imitation occurs when firms in the rest of the economy observe and copy 
production methods, and managerial and organizational techniques. Skills spillovers occur when skills acquired through employment and participation in the leading sector are transferred elsewhere in the economy through the movement of labor. Competition spillovers occur when the lead sector compels other firms through competition to become more efficient and adopt new technology at an accelerated rate. Export spillovers may occur if the leading sector is able to export and so enjoy scale economies and increased exposure to global-leading technology (Gorg \& Greenaway, 2004). There is a dearth of any work on spillovers and linkages from CPEC, which must be a research priority.

Theory reminds us that we should not forget politics. The intense debates among regional political leaders in Pakistan about re-routing CPEC to pass through their own political constituencies should be a timely reminder that support for $\mathrm{CPEC}$ is not just about its national benefits. We must not forget the local and the political considerations, as well. In their theory of white elephants, Robinson and Torvik (2005) demonstrate how infrastructure projects with negative social value may still be built. They see such unproductive investment as a means of inefficient redistribution that can only be credibly built by certain politicians who have a vested interest in a particular group or region. For such politicians these projects may be preferred to socially-efficient projects.

Our final lesson from old-fashioned theory is that transformational infrastructure is very different from marginal changes. Marginal infrastructure changes involve incremental gains such as alleviating bottlenecks, meeting obvious and immediate needs, cutting costs for producers and reducing travel time for commuters. The benefits from such changes should be quickly and clearly evident. The impact of a transformational change in infrastructure cannot be so easily measured or even anticipated. We are no longer considering just promoting a more efficient economy, but of "calling forth and enlisting for development purposes resources and abilities that are hidden, scattered, or badly utilized." (Hirschman, 1958). Economic growth then is not about the efficient allocation of resources, but if the "economy is to be kept moving ahead, the task of development policy is to maintain tensions, disproportions, and disequilibria" (Hirschman, 1958). In considering the success (or otherwise) of CPEC we should not expect to see only improvements but also considerable and often unexpected changes that may in turn be associated with significant adjustment costs, such as shortages of credit among firms desperate to expand, bankruptcy of firms 
no longer able to compete, and forced migration as workers move to growing areas.

\section{Problems with Existing Studies and a Proposed Methodology}

There are various existing studies of infrastructure, but they tend to be very narrow in their focus. Gulyani (2001) has studied the impact of the poor road system in India in the 1990s on the automobile firm Maruti. He found that poor roads directly raised the cost of freight, increased the cost of operations and maintenance (greater wear and tear and higher fuel consumption) and increased transit times making it longer to complete deliveries. As a result, Maruti was compelled to tie up large amounts of capital holding stocks and inventories. Gunasekara et al. (2008) examined the improvement of $350 \mathrm{~km}$ of roads in Sri Lanka in 1987 through the rehabilitation of two highways connecting Colombo and Kandy to the Northeast. This was not a transformative change but did lead to the number of vehicles on these roads increasing from 2000 to 8000 per day. After the renovation, firms near the highway were found to have more output, more employees, increased capital and reduced labor, more skilled employment and households living near the road experienced higher incomes.

Here, after examining old-fashioned economics, we can now turn to history which offers a wide range of case studies that bear a lot of similarity to CPEC. Recall that the route from Kashgar to Gwadar will be around 3,000 km (1,800 miles) and is scheduled to be completed over 15 years (2015 to 2030). The historical case studies have been chosen because they bear some important similarities to the CPEC in contemporary Pakistan. The infrastructure was built in then-developing economies largely through foreign investment, much of it mediated by a foreign government (typically the UK). Infrastructure in two cases led to rapid and sustained industrialization (Germany and the U.S.) and in the other two tended to boost agriculture or have a more muted impact on industry (Mexico and Russia). This distinction allows us to draw on contrasting experiences when thinking about possible lessons for contemporary Pakistan. Finally, the railways generated new economic opportunities, but in the context of the close presence to and competition with an industrially developed economy. For the case of India and Germany the leading industrial economy was the UK. The later constructions of railways in Mexico were overshadowed by both the UK and U.S., and in Russia by Germany, the UK and France. 
In India the first railway tracks were laid in 1854 and the 4,711 miles of track in 1860 had expanded to 37,029 miles by 1920 (Hurd, 1975)2. In the U.S., railways were first laid in the 1820s and during the 1850s there was a boom in construction. The 1850s saw around 22,000 miles of track being laid (Haines \& Margo, 2006). German railroad began later, in the early 1840s, and there were 14,518 miles by 1860 (Fremdling, 1977). In Russia the railway system grew from nothing in 1850 to 32,000 miles by around 1900 (Metzer, 1974). In Mexico the railway network expanded from 680 miles in 1880 to 12,400 miles in 1910 (Coatsworth, 1979; Dobado \& Marrero, 2005). In each of these cases, there is ample evidence to suppose these changes did not represent marginal changes but were 'transformative'. Prior to the railroad era, goods transport within India took place on roads, rivers and coastal shipping routes. Bullocks were either employed as pack bullocks (goods strapped to backs) and travelled over pasture land or cart bullocks, which pulled a cart containing goods, and travelled along improved roads. Before the railways, the overland commodity transport was dominated by Banjaras who travelled with huge herds of bullocks that sometimes numbered 10-20,000. Such a herd could move 6-8 miles per day and could only travel for a few months a year when animals could find food and water and not during the monsoon. In a year, such a herd could move an amount equivalent to that which a railroad could carry over an equal distance in a single week. In 1860, grain sold 100 miles apart between Aligarh and Bareilly (a route dominated by Banjaras) showed a three-fold price difference (McAlpin, 1974). Water transport was superior to road transport though only feasible on the Brahamputra, Ganges and Indus river system. To travel between Ahmedabad and Calcutta, it took around 20 days downstream and two or three months upstream. Coastal shipping was perennially available along India's long coastline; ocean-going steamships were fast after 1840 and could cover over $100 \mathrm{~km}$ per day, but could only service major ports (Donaldson, 2010). From the outset, railroads proved far superior to road, river or coastal transport. Railroads were able to travel $600 \mathrm{~km}$ a day and offered superior speed, predictable timetables, through all months of the year and railroad freight rates were also much cheaper (Donaldson, 2010). In a sample of 188 districts, only 14 were served by railroads by 1860 and 99 by 1880. By 1867, 19 of the 20 largest cities had a railroad (Hurd, 1975). In nineteenth century Russia, prerailway trade was conducted by river, canal and wagon. Waterways were

\footnotetext{
${ }^{2}$ Considerable debate remains about the motivation for this construction which has variously been explained by connecting cotton and rice producing regions to facilitate exports of these goods, to speed up troop movement between urban areas and to protect regions from crop failures (particularly after publication of the Famine Commission Report in 1880) (Andrabi \& Kuehlwein, 2010).
} 
frozen for six months a year. Transport had high cost and served only localized markets, and the volume of market output was relatively small, with much of it consumed or retained as a famine reserve (Metzer, 1974). In Mexico, there were no cheap alternatives to railway travel and the main population centers were far from the coast. As such, coastal shipping was not a realistic alternative (Coatsworth, 1979; Dobado \& Marrero, 2005).

There have been various attempts to measure the impact of these transformative changes. Fogel (1966) pioneered a method called 'social saving' to measure the incremental contribution of U.S. railroads to the U.S. economy. He defines 'social saving' as "the difference between the actual cost of shipping goods in a year and the alternative cost of shipping exactly the same goods between exactly the same points without railroads" (Fogel, 1966). He argued that even by the later nineteenth century, the extensive system of existing and potentially expandable waterways in the U.S. offered a reasonable alternative to railway transport. Despite the enormous infrastructural costs, he argued, by 1890 the social saving of railways only amounted to less than 3 percent of GDP. He notes, for example, that the main wheat and cotton growing regions and bulk of iron ore deposits were all located close to natural waterways. Fogel (1966) also argued that (contrary to the ideas of the 'leading sector') the growth of the railways accounted for only around 17 percent of the output of total iron production, less than 1 percent of total lumber output and 6 percent of total machine production.

There are predictably many criticisms of Fogel and his pioneering method. Fogel makes strong assumptions about the feasibility and likely impact on the costs of transport by shifting from the actual railways to a counter-factual, the waterways. Fogel based his estimates on the actual market prices of waterway transport in the 1890s without accounting for the possibilities of rising costs if waterways were burdened with the extra traffic then carried by railways. Fogel makes no mention of the comfort and convenience of passenger travel. This activity generated 25 percent of operating revenues for the railroad companies in 1890. Fogel does not account for the importance to the U.S. of massive grain exports in the nineteenth century which provided the foreign exchange necessary to import the capital goods and technology needed for industrialization. The export of grain on a large scale would have been difficult without railways. While Fogel focused on the expansion of the cultivated area of grain he paid little attention to the greater ease of regional agricultural specialization and internal trade afforded by railways (as noted later in this article). Fogel also neglected to consider the impact of railways on risk and consumption patterns. The reduction of risk by reducing the vulnerability of previously self-sufficient regions and allowing 
inter-regional and international trade is difficult to quantify. The more even flow of grain throughout the year via railways allowed consumers to move away from seasonal consumption patterns and to maintain consumption levels more evenly throughout the year (David, 1969; White 1976). The root of the methodological problem is that there are so many potential changes induced by a transformational change in infrastructure that it is impossible to convincingly account for all of them or more generally that there are "deficiencies of partial analyses, which accept the existing structure of prices and production" (David, 1969).

Another potential method which avoids many of these problems is a before and after comparison. Haines and Margo (2006), for example, measure rail access in the U.S. at the county level using information derived from maps to show whether a rail line passed through county boundaries in 1850 or 1860 (or both). They then link rail access data to county level information on economic outcomes in 1850 and 1860 . They use a difference-in-difference approach comparing outcomes in the treated group (counties that gained rail access in the 1850s) with a control group before and after gaining rail access using 672 counties from 14 states. While more satisfying in some ways, this method couldn't be carried out in Pakistan until well after 2030 - when CPEC has been completed and we can begin thinking about comparing before and after. The method used in this paper is to draw from historical studies and think about their likely relevance for the case of CPEC in contemporary Pakistan.

\section{Markets More Efficient}

While this paper has drawn on old-fashioned economics, many of the historical case studies have also utilized very conventional economics and focused on how transformative infrastructure has influenced the efficiency of markets. The implication being drawn from neo-classical economic theory is that economic growth is best promoted with freely functioning and competitive markets. Such orthodox theory predicts that where a profit opportunity exists, somebody will take it. Where prices and profits are high, commodities will be moved until prices and profits decline to an average through arbitrage. Prior to railway construction in India and elsewhere, owing to prohibitive transport costs and absent information on arbitrage opportunities across much of the world, different regions and districts were not in the same market. Hence, prices differed widely across different climactic zones and the movement of these prices was unrelated. There is widespread evidence that transformative infrastructure led to price convergence. 
In India, prior to the railways, some regions were perennially short of grain or had frequent famines, while others had a relative abundance of food. In the 1860s, the prices of grains in some districts were eight to ten times higher than the prices in others. In India the railways caused transportation costs to fall by approximately 80 percent per mile and trade in bulk goods was made possible. By 1910 almost 3 million tons of wheat were carried by rail amounting to around 30 percent of the wheat crop (and also 14 percent of the rice crop). Historical India has an abundance of foodgrain price information that was collected by the British colonial state from 1861 onwards at a disaggregated level of detail. Price data reveals a decline in the coefficient of variation between districts from the mid-nineteenth to the early twentieth century, which coincides exactly with the era of railway construction (Hurd, 1975). Between 1876 and 1910, the coefficient of variation in the average prices of rice in around 70 sub-divisions of Bengal showed a secular decline and lower seasonal price variations (Mukherjee, 1980). Donaldson (2010) used seven million observations on district-level prices, output, daily rainfall and inter-regional and international trade in India. He found that railroads reduced trade costs, the responsiveness of prices to local weather shocks, inter-regional price gaps, real income volatility, and increased trade volumes and income levels. He found the timing of connection to a railway link was clearly correlated to rising real incomes in districts (by an average of 18 percent). Such links though had the effect of reducing income in neighboring districts by an average of 4 percent. The detail of this study was striking. Among other data, Donaldson (2010) used the all-India network of 3,614 meteorological stations that recorded the amount of rainfall at each station on every day of the year to link local rainfall to local crop output and combined these data with a newly created digital map of India's railroad network in which each $20 \mathrm{~km}$ segment was coded with its year of opening. One problem with such studies that purport to show railways were correlated with economic success is that they were often built in areas already experiencing economic growth. Haines and Margo (2006) for example found that gaining access to railways was correlated with existing access to water transport and that more densely populated areas were more likely to gain access to railways. Controlling for such factors reduces the effects significantly but preserves the impact of railways on market efficiency. Andrabi and Kuehlwein (2010) examine the effect of railway construction on price dispersion in annual retail wheat and rice prices in over 150 Indian districts between 1860 and 1920. They have found that railways can explain only 10 percent of the decline in the relative price gap that we observe over these 60 years. The bulk of the effect they suggest can be accounted for by other factors such as the spread of the 
telegraphy and postal service which improved information flows, the construction of paved roads which improved road-based bullock transport, the greater peace and uniformity in the all-India legal system after the ending of the 1857 uprising, the spread of a single currency and the abolition of internal tolls which hindered inter-regional trade.

Elsewhere Dobado and Marrero (2005) have found that between 1885 and 1908 inter-state differences in corn prices declined in Mexico and that railways played a significant role. The speed of price convergence of those states with railroads in 1884 more than doubled those of the states without them. In Russia there was a clear decline in price differentials starting in the 1870s with the first surge in railway construction between wheat prices in Odessa and St Petersburg, as well as various other regional markets such as Odessa-Moscow and Riga-Moscow. There was a rapid commercialization of rye, previously a subsistence product, and a rise in the share of the harvest that was marketed. About 83 percent of the decline in price differentials could be attributed to railways, which induced a decline in transportation costs (Metzer, 1974).

The relevance of these studies for contemporary Pakistan is limited. Even before CPEC was launched, there is evidence that markets were already efficient in Pakistan. Price data show that there was rapid convergence of prices across ten major cities of Pakistan between 2000 and 2011 (Alam \& Bhatti, 2014), 35 Pakistani cities between 2001 and 2008 (Mohsin \& Gilbert, 2010), and of food commodities (but less so other commodities) between 35 Pakistani cities between 2001 and 2011 (Ghauri et al., 2013). Therefore, the benefits of CPEC infrastructure are not likely to emerge from more efficient price convergence and the creation of national markets.

A key result from this work is that some regions gain and some regions lose. In India by 1914, around 18 percent of agricultural production by value was marketed over long or medium distances. This generated a process of greater regional specialization in the cultivation of marketoriented cash crops such as cotton, sugarcane, indigo, and poppy. Across India cultivation shifted to high yield areas and away from areas close to rivers. Cotton cultivation came to an end in low yield areas in the United Provinces (which grew a low-quality, short-staple variety) and Central, Northern and Eastern Oudh. Cotton became increasingly concentrated in the Middle Doab where yields were highest and where the plant could be sown early as part of the double cropping mix (Derbyshire, 1987). The United Provinces became the great sugar-province of the sub-continent with a 30-50 percent increase in its sugarcane acreage being recorded between 
1860 and 1895. During the same period, sugarcane acreage fell in Western and Central India (Derbyshire, 1987). All these changes generated winners and losers. In the United Provinces there is no reason to suppose cotton farmers who lost out could have transferred production to benefit from growing sugarcane. As noted above, Donaldson (2010) has found that districts adjacent to newly constructed railways experienced income increases and those further away experiences declines in income. This is not surprising as businesses may go bankrupt or seek to re-locate in areas further away from railway lines to participate in new growth opportunities. There is the danger of polarization in response to growing inequalities of opportunity created by transformative infrastructure. This is highly relevant for the case of contemporary Pakistan which has long experienced striking regional inequalities in economic growth (Zaidi, 1992).

Recent work has emphasized that patterns of specialization have different implications for long-run economic growth. Specialization in agriculture or low-technology production may lock-in a region or country to long-run patterns of slower economic growth (Deraniyagala \& Fine, 1999). In this view the very efficiency of the railway system in nineteenth century India (or, as discussed below, Mexico) locked the economy into long-run slow economic growth.

A key safety valve for regional polarization has historically been the migration of people from the poor to the fast-growing areas of the economy. If a region or state has 'poor geography', the constraint to aggregate growth can be overcome by people moving to better endowed regions/states. Hundreds of millions of people in contemporary India remain stuck in the Gangetic heartland, in some of the poorest states Madhya Pradesh, Rajasthan, and Bihar. There is no indication of mass migration to the more rapidly growing coastal states of Gujarat or Maharashtra, for example. India has long been handicapped in this regard by relatively low levels of migration. There was little migration and wage convergence in the nineteenth century (Collins, 1999) and this pattern continued into the period between 1960 and 1990 (Cashin \& Sahay, 1996). A representative sample of rural Indian households found that the likelihood of male migration actually declined between 1982 and 1999 despite growing wage inequality between states and urban-rural areas (Munshi \& Rosenzweig, 2005). In India "[t]he highest level of movement are recorded within the same district. The flow of migrants across state lines is a trickle. Since 2001 there has been a slowdown in permanent or long-term migration" (World Bank, 2009). By contrast, in the more mobile U.S., over the course of a decade a quarter of the population changes its 
state of residence (World Bank, 2009). In China over the 1980s and 1990s perhaps 100 million people moved from inland to rapidly growing coastal China. This immobility in India has been ascribed to various reasons: the location-based welfare programs such as subsidized food and land reform, the restrictions on marriage outside the sub-caste/jati which restrict partner choice to a local pool, kinship- and caste-based insurance networks that would be undermined by migration, and the enormous linguistic, religious and caste diversity. Migration in India is also associated with constructed political constraints. The influential Shiv Sena party in Mumbai, for example, have a dedicated program to keep the city a preserve of the locally born. Pakistan, by contrast, was a country born of migration. Soon after independence, more than 50 percent of the populations of major urban areas - Karachi, Lahore, Hyderabad - were composed of migrants. There are no directly comparable studies with India, but evidence for Pakistan suggests migration has continued at a high level over the subsequent decades (Perveen, 1993). Tension and conflict have been prevalent, such as conflict over jobs and urban living space in Karachi during the 1990s, but this hasn't hindered long-term migration. By 2000, ethnic Sindhis were a tiny minority of the urban population of Sindh (Ahmar, 1996; Khan, 2002).

The other important lesson we can learn from this historical literature is that infrastructure, even if transformative, is not sufficient to create efficient markets and ensure the flexible allocation and re-allocation of commodities and factors of production. Estimates of the impact of railway infrastructure on price convergence ranged from 10 to 80 percent of the total convergence. In contemporary Pakistan there are welldocumented constraints on economic growth that will not be tackled by transformative infrastructure. These include competition from other countries such as Vietnam, corruption (in 2013 Pakistan ranked 127 from 175 countries in the Corruption Perception Index produced by Transparency International, TI), regulatory burdens, the business climate, political instability, and the availability of skilled labor (Amjad et al., 2015).

\section{Industrialization or De-Industrialization}

To understand more fully the impact of transformative infrastructure in the historical settings discussed in the previous section, we need to go beyond the neo-classical assumption that efficient markets are necessarily good and ask instead, efficient at what? 
Various authors have argued that the railways in colonial India were so efficient that they facilitated the import of British manufacturing goods and undermined domestic industrialization in India. The arrival of the Indian railways coincided with a significant change in the composition of exports, imports and domestic production. In the nineteenth century, new export commodities emerged such as indigo, opium and cotton. India's traditional cotton textile industry declined between 1820 and 1860. Initially, the export market for Indian cloth disappeared, and later, handspun cotton yarn and handwoven cloth declined in response to competition from imports of yarn and cloth produced in English mills (Roy, 2002). By 1880-81 British manufacturers were supplying more than half of total consumption (Habib, 2006). Other sectors to decline were the jute handloom weaving and silk of Bengal, Kashmir shawl manufacture in Srinagar, hand paper, glass, and iron (Habib, 2006).

More efficient markets did not prevent devastating famine. The estimated mortality from starvation and disease crossed 1 million in the Deccan in 1876-78, and North West Provinces in 1877-78. There were countrywide famines in 1896-97 (an estimated 4.5 million dead) and 1899-90. The Orissa famine in 1865-66 was clearly a pre-railway age famine, as crops failed in an area without roads and ports and the region could not receive supplies from outside. It was expected that as the railway network spread, supplies would move in from cheaper/surplus areas and famine would be alleviated. The famine in 1868-69 in the North West Frontier occurred in an area wellsupplied by railways and so refuted this notion. The railways had instead facilitated a general shift to producing cash crops for trade rather than food crops for local consumption. The output of food crops per head stagnated in British India from $282.41 \mathrm{~kg}$ in 1885 to $287.95 \mathrm{~kg}$ in 1895 (Habib, 2006). The second effect of the railways was to connect inland areas to ports which facilitated the export of food-grains, especially rice and wheat. In 1875, British Indian ports exported 1.22 million tons of food-grains and in 1895 about 2.49 million tons, representing 2.3 percent and 3.9 percent of estimated food-grain production, respectively. In 1896-98 and 1899-90, exports would have been enough to avert famine (Habib, 2006). Others have emphasized the more positive efficiency impacts of the railways. The Indian National Congress met for the first time in Bombay 1885 and could not have done so with the railways which brought in delegates from the provinces. If railways contributed to colonial exploitation, then they also contributed to the growth of nationalism. The growing Indian press depended on railways for their circulation (Rothermund, 1993). The postal system was started in the 1850s and mail was carried by the railways. The number of letters and packets carried by post increased from 85 million in 1869 to 1,043 million in 1914 (Habib, 2006). 
Another example is that of Mexico in the Porfirian era (1877-1910). Before the railroad, Mexico depended almost exclusively on overland transportation. Mexico, unlike Russia, the U.S. and Britain, had no river system suitable for use in transport. Most of the Mexican population and economic activity has traditionally been located far from the two coasts in plateaus and mountain valleys, so coastal shipping never played the role it did in Europe and the U.S. Unit savings on railway freight operations were enormous, with an estimated social saving of around 25 percent of GDP. Local entrepreneurs and foreign capitalists responded to changing market incentives with the result that modern mining and agricultural export industries boomed. Railroads promoted Mexican economic growth by reinforcing the country's comparative advantage in the production of minerals and, to a lesser extent, fibers for export. On the Mexican Central Railway (the longest in Mexico) minerals and fibers amounted to 1.3 percent of total freight tonnage in 1885 and 58.2 percent in 1908. It is likely that the export sector received at least 75 percent of the benefits of the operation of the railways in Mexico by 1910. The construction and operation of the railways was also heavily import-dependent. Imported inputs as a percentage of total operating costs increased from 29.3 percent in 1896, to 48.0 percent in 1900, 25.1 percent in 1905 and 32.3 percent in 1906. The extreme levels of export- and import-dependence of Mexico during these years meant that the railways generated very few backward linkages to stimulate domestic industry. Railroads were constructed and operated with rails, locomotives, rolling stock, spare parts, iron bridges and supervisory/engineering personnel imported from abroad. On occasion, even fuel (coal and wood), ties for laying tracks and unskilled labor were imported (Coatsworth, 1979).

In nineteenth century Germany, by comparison, the railways stimulated widespread backward linkages to local industry. When railway construction began in the mid-1830s, the German engineering and iron industries were backward and not capable of producing the main investment goods such as rails and locomotives. For example, in 1835 more than 90 percent of the pig iron was produced in small charcoal-using furnaces. In the first years of railroad construction, foreign, mainly British, suppliers dominated the market. By the beginning of the 1840s, the substitution for these imports by domestic production had begun. Many iron processing plants using modern British technology were established and existing ones enlarged their capacity. By the 1850s, most of the rails were produced in Germany. After 1854, all locomotives except a few from Austria were supplied by German producers (Fremdling, 1977). The sequence and speed of import substitution was promoted by a tariff policy that protected 
the wrought-iron industry by levying heavy duties on all processed iron products. Catching up with British technology was possible through deliberate imitation and borrowing. Foreign technology was transferred through leading German manufacturers traveling and studying in France and Britain, through employment of French, Belgian and British engineers and skilled workers (for example, puddlers and roll-masters), and through foreign investors founding firms, especially French ironmasters in the Ruhr and Rhine area (Fremdling, 1977). This was a general process of the state taking on a more direct and guiding role in relation to domestic industry after 1840 . The state promoted infant industry through tariff protection, state investment, public-private cooperation and various subsidies. The state also gave scholarships to promising innovators, subsidies to competent entrepreneurs, and directly facilitated the organization of new machinery and industrial processes (Chang, 2002).

There is a well-established body of literature that explores the criteria necessary for a state to be developmental in the style of nineteenth century Germany and so ensure that the benefits from a project like CPEC promote domestic economic growth rather than leak out overseas. These preconditions include: that leaders have a politically-driven desire to promote growth; that state institutions are autonomous; the bureaucracy is competent and insulated from politics; that civil society is weak; and that the state enjoy widespread legitimacy, whether of the democratic variety or other (Leftwich 1995, 2000). Unfortunately, there is good evidence that the capacity of the state in Pakistan is declining. The Global Competitiveness Reports compile indices, ranging from 1 to 7 (7 being the best) to measure various aspects of governance. Table 1 compares the reports from 2006-07 and 2014-15 which reveal a widespread deterioration in state capacity, across the quality of institutions, judicial independence excepted, favoritism in government decision-making, waste in government spending, and an improving if poor measure of the reliability of the police.

Table 1: Declining State Capacity in Pakistan

\begin{tabular}{lcc}
\hline Measure of Governance & $\mathbf{2 0 0 6 / 0 7}$ & $\mathbf{2 0 1 4 / \mathbf { 1 5 }}$ \\
\hline Quality of Institutions & 3.5 & 3.2 \\
Judicial Independence & 3.3 & 3.8 \\
Favoritism shown in decisions of government officials & 3.1 & 2.6 \\
Wastefulness of Government Spending & 3.5 & 2.6 \\
Reliability of Police & 3.1 & 3.1 \\
\hline
\end{tabular}

Source: World Economic Forum (2006). The Global Competitiveness Report, 2006-07, Geneva, Switzerland and World Economic Forum (2014). The Global Competitiveness Report, 2014-15, Geneva, Switzerland. 
One practical example is the Medium-Term Development Framework for 2005 to 2010, launched by the Government of Pakistan with the aim to provide basic infrastructure to promote sustained economic growth. The effort was evaluated by the Asian Development Bank (2013). The evaluation found that efforts at inter-departmental cooperation and coordination were a failure and the work was eventually implemented separately by line ministries. A significant lack of government capacity to identify projects through feasibility studies and to bring them to the bidding stage was also noted, and the government was unable to ensure contract and licensing enforcement. The absence of a long-term debt market and no long-term financing was identified as an enduring constraint on infrastructure financing. Not surprisingly, almost none of the targeted outcomes were achieved in practice.

As noted, the developmental state theorists argue that a key criterion for a state to be developmental is a bureaucracy that is autonomous and therefore empowered to take a long-run growth-promoting view of the economy that is not side-tracked by the populist and short-term demands of politicians. The reality is very different in contemporary Pakistan. State capacity is declining and the state has become increasingly subordinate to the demands of civil society. The relationship between state and society in Pakistan is one of patronage between politicians and supporters or dependents, such that "people gain access to patronage by using their position within a kinship network to mobilize support for a politician who then repays them in various ways in office, or by using kinship links to some policeman or official to obtain favors for relatives or allies" (Lieven, 2011). The process can be likened to state fiscal resources being "nibbled by a plague of mice" (Lieven, 2011). The state fails to provide public services such as water, education and power, because it is too weak to raise tax revenue and to control corruption among state officials. Corruption is not just about individual gain but is also for patronage, whereby state resources are recycled by politicians to win, retain and reward supporters and kinship groups.

\section{Conclusion and a Research Agenda}

There is widespread agreement that CPEC is a transformative infrastructure project and will be a success. It has become a key part of the discourse surrounding the contemporary debate on the economics of Pakistan. It is worth pausing here, as while there is much research on the geopolitical implications of $\mathrm{CPEC}$, there is very little existing research on the likely economic outcome of the CPEC. 
Old-fashioned economics has given us some key theoretical ideas from scholars who thought in terms of transformational changes - usually the shift away from a rural-agricultural economy to an urban-industrial one. Such theory gives us the means to think about the likely impacts of CPEC and of some of the preconditions for it to be a success. A key idea is that of leading sectors, where one sector expands and pulls up the wider economy through positive spillovers. While the CPEC could become a leading sector there are plenty of historical examples of expensive infrastructure projects than ended up in costly and splendid isolation from the rest of the economy. The decaying and underused Olympic Games projects in many countries are perhaps the most notorious such examples. The current and likely spillovers need to be studied further, focusing on those relating to imitation, skills, competition and exports. We must also give careful consideration to the politics of CPEC. Does the wide support for CPEC represent a Rostowian elite commitment that will help ensure it works successfully? Does CPEC represent a new national idea or consensus that has eluded so many other reformist efforts in the past? Are its many supporters genuinely anticipating that it will contribute to the national economic revival of Pakistan or hoping that some of the resources associated with its construction and operation will benefit them and their constituents? History offers us much evidence of the impacts of transformational infrastructure, their successes and failures. We can draw from these studies and their various methodologies of counter-factual history and before-after approaches to think carefully about whether CPEC is likely to be successful in contemporary Pakistan.

There is widespread evidence that transformational infrastructure does tend to make markets more efficient in the sense of reducing time and spatial price divergences. This is of little relevance for contemporary Pakistan where spatial price differences have already tended to converge before the launch of the CPEC. The potential transformational impact of CPEC needs to look for changing patterns of regional specialization in production and its impact on changing patterns of migration.

Further we need to ask the question of efficient to accomplish what? Improved markets and transport links between China and Pakistan could lead to the growth of manufacturing production in Pakistan, to Pakistan being bypassed and becoming merely a transit route for Chinese exports travelling to the rest of the world, or for Pakistani manufacturing production to be displaced by imports from China. Each of these outcomes could represent the working of efficient markets. A brief consideration of Pakistan offers little cause to be optimistic. Existing studies looking at the constraints 
to manufacturing growth need to be reviewed. Just how important is infrastructure as a constraint relative to absent long-term credit, education, political instability, governance and difficulties in accessing land for industrial development. The Pakistani state has no vision to utilize the construction of CPEC to promote domestic industrialization. There is no indication that a domestic industrial policy will be utilized to ensure that the opportunities of CPEC are manifested in domestic industrial growth rather than in more industrial imports. The Pakistani state lacks the capacity to be developmental even if it did seek to acquire and utilize just such an industrial policy. Recent evaluations of efforts to promote infrastructural growth have been negative. There is a need for more research certainly, but perhaps also for a dash of realism about the prospects for CPEC.

There is much of importance that this article does not cover that could also be considered in future studies. Firstly, the focus of this paper is narrowly on economic growth rather than issues of wider development. The likely impact of CPEC on livelihoods would represent an important extension of this research. While CPEC is promising the creation (or diversion) of at least 30,000 security posts to protect its investments (Boyce, 2017), others will inevitably have to surrender their lands and associated livelihoods for the construction of the new infrastructure. Secondly, this article does not consider the financing of CPEC. Will it lead to excess profits among outside investors supported by government guarantees and subsidies? This was one mechanism by which the economic advantages of railways in colonial India were argued to have benefited the British rather than the domestic Indian economy (Habib, 2006). Will CPEC lead to an excessive level of external debt creation and so to long-term debt dependence? Here there are grounds for some optimism. The US\$12 billion financing of infrastructure has been undertaken at interest rates of around 1.6 percent (Boyce, 2017). This is more generous lending than, for example, the high interest rates used to finance massive developing country infrastructure investments in the 1970s that collapsed in the global debt crisis of the 1980s. Finally, this article focuses on the infrastructure side of CPEC rather than the energy investments - the latter has already been widely researched and the benefits of better electricity supply seem much more clearly apparent (Siddiqui et al., 2011). 


\section{References}

Ahmar, M. (1996). Ethnicity and state power in Pakistan: The Karachi crisis. Asian Survey, 36(10), 1031-1048.

Ahmed, I. \& Qayyam, A. (2007). Do public expenditure and macroeconomic uncertainty matter to private investment? Evidence from Pakistan. The Pakistan Development Review, 46(2), 145-161.

Amjad, R., Chandrasiri, S., Nathan, D., Raihan, S., Verick, S., \&Yusuf, A. (2015). What holds back manufacturing in south Asia. The Economic and Political Weekly, March 7, 36-45.

Alam, A. \& Bhatti, A.A. (2014). Relative Commodity Price Convergence in Pakistan, mimeo.

Andrabi, T. \& Kuehlwein, M. (2010). Railways and price convergence in British India. The Journal of Economic History, 70(2), 351-377.

Asian Development Bank (2013). Pakistan: Private participation in infrastructure program. Validation Report PVR-300, Manila, Philippines.

Atique, Z, Khan, M.H., \&Azhar, U. (2004). The impact of FDI on economic growth under foreign trade regimes: A case study of Pakistan. The Pakistan Development Review, 43(4), 707-718.

Balakrishnan, P. (2006). Benign neglect or stategic intent? Contested lineage of Indian software industry. Economic and Political Weekly, Sept. 9, 3865-3872.

Birdsall, N. \& Kinder, M. (2010). The US aid surge to Pakistan: Repeating a failed experiment: Lessons for US policymakers from the World Bank's social-sector lending in the 1990s. Centre for Global Development Working Paper, No. 205, Washington.

Bloom, D.E., Sachs, J.D., Collier, P., \& Udry, C. (1998). Geography, demography, and economic growth in Africa. Brookings Papers on Economic Growth in Africa, 1998(2), 207-295.

Boyce, T. (2017). The China-Pakistan economic corridor: Trade security and regional implications. Sandia Report, California. 
Cashin, P. \& Sahay, R. (1996). Internal migration, center-state grants, and economic growth in the states of India. IMF Staff Papers, 43(1), 123-171.

Chakraborty, C. \& Jayachandran, C. (2001). Software sector: Trends and constraints. Economic and Political Weekly, August 25th, 3255-3261.

Coatsworth, J.H. (1979). Indispensable railroads in a backward economy: The case of Mexico. The Journal of Economic History, 39(4), 939-960.

Collier, P. (2007). The bottom billion: Why the poorest countries are failing and what can be done about it. Oxford, Oxford University Press.

Collins, W.J. (1999). Labor mobility, market integration, and wage convergence in late $19^{\text {th }}$ century India. Explorations in Economic History, 36, 246-277.

Coulibaly, S, \& Fontagne, L. (2005), South-south trade: Geography matters. Journal of African Economies, 15(2), 313-341.

David, P.A. (1969). Transport innovation and growth: Professor Fogel on and off the rails', The Economic History Review, 22(3), 506-525.

Deraniyagala, S. \& Fine, B. (1999). New trade theory versus old trade policy: A continuing enigma. Cambridge Journal of Economics, 25, 809-825.

Derbyshire, I.D. (1987). Economic change and the railways in north India, 1860-1914. Modern Asian Studies, 21(3), 521-545.

Diamond, J. (1999). How to get rich. The Edge, 56, 8-18.

Dobado, R. \& Marrero, G.A. (2005). Corn market integration in Porfirian Mexico. The Journal of Economic History, 65(1), 103-128.

Donaldson, D. (2010). Railroads of the Raj: Estimating the impact of transportation infrastructure. LSE Asia Research Centre Working Paper, 41, London.

Fogel, R.W. (1966). Railroads as an analogy to the space effort: Some economic aspects. The Economic Journal, 76(301), 16-43. 
Fremdling, R. (1977). Railroads and German economic growth: A leading sector analysis with a comparison to the United States and Great Britain. The Journal of Economic History, 37(3), 583-604.

Gallup, J.L \& Sachs, J.D. (1999). Geography and economic development. Centre for International Development Working Paper, 1, Harvard University.

Ghani, E \& M-Ud.Din (2006). The impact of public investment on economic growth in Pakistan. The Pakistan Development Review, 45(1), 87-98.

Ghauri, S.P., Qayyum, A. \& Arby, M.F. (2013). Price level convergence: Evidence from Pakistan cities. Pakistan Economic and Social Review, 51(1), 1-12.

Gorg, H. \& Greenaway, D. (2004). Much ado about nothing? Do domestic firms really benefit from foreign direct investment. The World Bank Research Observer, 19(2), 171-197.

Government of Pakistan (2017). Long term plan for China-Pakistan economic corridor 2017-2030. Ministry of Planning, Development and Reform, Islamabad.

Gulyani, S. (2001). Effects of poor transportation on lean production and industrial clustering: Evidence from the Indian auto industry. World Development, 29(7), 1157-77.

Gunasekara, K., Anderson W. \& Lakshmanan, T.R. (2008). Highwayinduced development: Evidence from Sri Lanka. World Development, 36(11), 2371-2389.

Habib, I. (2006). Indian Economy, 1858-1914. New Delhi, Tulika Books.

Haines, M.R. \& Margo, R.A. (2006). Railroads and local economic development: The United States in the 1850s. NBER Working Paper Series, No. 12381, Cambridge, MA

Hali, S. M., Shukui, T. \& S.Iqbal, S. (2015). One belt and one road: Impact on China-Pakistan economic corridor. $h$, 34(4), 147-164.

Hirschman, A.O. (1958). The Strategy of Economic Development. New Haven, Yale University Press. 
Hurd, J. (1975). Railways and the expansion of markets in India, 1861-1921. Explorations in Economic History, 12, 263-288.

Hyder, K. (2001). Crowding out hypothesis in a vector error correction framework: A case study of Pakistan. The Pakistan Development Review, 40(4), 633-650.

Kapur, D. (2007). The causes and consequences of India's IT boom. in B.R. Nayar (2007) (Ed). Globalization and Politics in India, New Delhi, Oxford University Press.

Khan, A. (2002). Pakistan's Sindhi ethnic nationalism: Migration, marginalisation and the threat of Indianisation. Asian Survey, 42(2), 213-229.

Khan, A.H. (1988). Macroeconomic policy and private investment in Pakistan. The Pakistan Development Review, 27(3), 277-291.

Kite, G. (2013). India's software and IT services revolution: A teacher to treasure. Economic and Political Weekly, July 27, 64-172.

Kurian, N.J. (2000). Widening regional disparities in India: Some indicators. Economic and Political Weekly, February 12, 539-550.

Leftwich, A. (1995). Bringing politics back in: Towards a model of the developmental state. Journal of Development Studies, 31(3), 400-427

Leftwich, A. (2000). States of development: On the primacy of politics in development. Cambridge, Polity Press.

Lieven, A. (2011). Pakistan: A hard country. London, Allen Lane.

Loayza, N. \& Wada, T. (2012). Public infrastructure trends and gaps in Pakistan. World Bank Policy Paper Series on Pakistan, PK 10/12, Washington.

McAlpin, M.B. (1974). Railroads, and peasant rationality: India 1860-1900. The Journal of Economic History, 34(3), 662-864.

McCartney, M. (2011). Pakistan, growth, dependency and crisis, 1951-2009. The Lahore Journal of Economics, 16(SE), 71-94. 
McCartney, M. (2015). Economic Growth and Development: A Comparative Introduction', London, Palgrave MacMillan.

Metzer, J. (1974). Railroad development and market integration: The case of Tsarist Russia. The Journal of Economic History, 34(3), 529-549.

Milner, C., Morrissey, O., \& Rudaheranwa, N. (2000). Policy and nonpolicy barriers to trade and implicit taxation of exports in Uganda. Journal of Development Studies, 37(2), 67-90.

Mohsin, H.M., \& Gilbert, S. (2010). Relative city price convergence in Pakistan: Empirical evidence from spatial GLS. MPRA Paper No. 27901, Munich.

Mukherjee, M. (1980). Railways and their impact on Bengal's economy, 18701920. The Indian Economic and Social History Review, 17(2), 191-209.

Munshi, K., \& Rosenzweig, M.R. (2005). Why is mobility in India so low? Social insurance, inequality and growth. CID Working Paper No 121, Harvard University.

Naqvi, N.H. (2002). Crowding out or crowding in? Modelling the relationship between public and private fixed capital formation using co-integration analysis: The case of Pakistan. The Pakistan Development Review, 41(3), 255-275.

Nordhaus, W.D. (2006). Geography and macroeconomics: New data and new findings. Proceedings of the National Academy of Sciences, 103(10), 3510-3517.

Robinson, J.A., \& Torvik, R. (2005). White elephants. Journal of Public Economics, 89, 197-210.

Rosenstein-Rodan, P.N. (1943). Problems of industrialisation of eastern and south-eastern Europe. Economic Journal, 53(210/211), 202-211.

Rostow, W.W. (1956). The take-off into self-sustained growth. Economic Journal, 66(261), 25-48.

Rostow, W.W. (1960). The stages of economic growth: A non-communist manifesto. Cambridge, Cambridge University Press. 
Roy, T. (2002). Economic history and modern India: Redefining the link. Journal of Economic Perspectives, 16(3), 109-130.

Sachs, J.D., McArthus, J.W., Schmidt-Traub, G., Kruk, M., Bahadur, C., Faye, M. \& McCord, G. (2004). Ending Africa's poverty trap. Brookings Papers on Economic Activity, 1, 117-240.

Sial, S. (2014). The China-Pakistan economic corridor: An assessment of potential threats and constraints. Conflict and Peace Studies, 6(2), 1-20.

Siddiqui, R., Jalil, H.H., Nasir, M., Malik, W.S. \& Khalid, M. (2011). The cost of unserved energy: Evidence from selected industrial cities of Pakistan. PIDE Working Papers 2011(75), Islamabad.

Summers, T. (2016). China's new silk roads: Sub-national regions and networks of global political economy. Third World Quarterly, 37(9), 1628-1643.

Warner, A. (2002). Institutions, geographic regions, countries and the mobility bias. CID Working Paper No.91, Harvard University.

Weisskoff, R. \& Wolff, E. (1977). Linkages and leakages: Industrial tracking in an enclave economy. Economic Development and Cultural Change, 25(4), 607-628.

White, C.M. (1976). The concept of social saving in theory and practice. The Economic History Review, 29(1), 82-100.

World Bank (2009). World Development Report 2009: Reshaping Economic Geography. Washington, D.C.

World Economic Forum (2006). The Global Competitiveness Report, 2006-07', Geneva, Switzerland.

World Economic Forum (2014). The Global Competitiveness Report, 2014-15', Geneva, Switzerland.

Zaidi, M.A. (1992). Relative poverty in pakistan: An estimation from the household income and expenditure survey (1984-85). The Pakistan Development Review, 31(4), 955-974. 